Ewa Bojenko-Izdebska

Kraków

\title{
STRATEGIA BEZPIECZEŃSTWA AUSTRII W XXI WIEKU
}

Neutralność była w Austrii zawsze interpretowana jako kategoria z zakresu prawa międzynarodowego i zobowiązanie wobec społeczności międzynarodowej, co odróżniało to państwo od prowadzących politykę neutralności Szwecji czy Finlandii. Narzucona Austrii w Traktacie państwowym z 15.05.1955 r. wieczysta neutralność została zaakceptowana przez społeczeństwo oraz elity rządzące. Późniejszy korzystny rozwój gospodarki, obecność instytucji ONZ i aktywność Austrii w tej organizacji, powszechnie uważano za konsekwencję tego wyboru, a edukacja dotycząca neutralności obejmowała nie tylko społeczeństwo, ale również austriackie siły zbrojne (Bundesherr) ${ }^{1}$.

Po zakończeniu zimnej wojny akcesja Austrii do Unii Europejskiej, najbardziej zaawansowanej w negocjacjach ze Wspólnotami ze wszystkich państw przyjętych w 1995 r., oznaczała konieczność zrewidowania interpretacji neutralności. Wraz z zasadniczymi zmianami zachodzącymi w UE stanowisko Austrii ulegało zmianom. W tym kontekście szczególne znaczenie miała Wspólna Polityka Zagraniczną i Bezpieczeństwa (WPZiB), a przede wszystkim pozostająca nadal jej integralną częścią, lecz wyodrębniona z niej w 1999 r. Europejskiej Polityki Bezpieczeństwa i Obrony (EPBiO) $)^{2}$.

Federalny Prezydent Austrii, Heinz Fischer, w wykładzie wygłoszonym w Uniwersytecie w Zurychu wskazał na silne kontrowersji wokół neutralności, szczególnie pod koniec lat 90. Podziały przebiegały wówczas między oboma głównymi partiami - socjaldemokratami z SPÖ, dla

${ }^{1}$ Por. P. Luif, Zehn Thesen zur österreichischen Neutralität. Gravierende Fehldeutungen der EU-Entwicklung w: „Neue Zürcher Zeitung. Internationale Ausgabe”, 28.8.2000, nr 199, s. 5.

${ }^{2}$ Po Traktacie Lizbońskim od 2009 r. Wspólna Polityka Bezpieczeństwa i Obrony (WPBiO), w tekście nazwa historyczna. 
których wstąpienie do UE oznaczało wzmocnienie neutralności - a centroprawicową ÖVP, która widziała w akcesji możliwość relatywizacji, a nawet odejścia od neutralności. Debata wokół ewentualnego członkostwa w NATO przyczyniła się w dużym stopniu do rozpadu koalicji SPÖ/ ÖVP, na przełomie 1999/2000 roku3 .

Prezydent wymienił też trzy podstawowe zasady austriackiego członkostwa w UE: „nieuczestniczenie w wojnie, nieprzystępowanie do sojuszu militarnego oraz niestacjonowanie obcych oddziałów na terytorium Austrii" ${ }^{\prime \prime}$ W odniesieniu do zapisów Traktatu Lizbońskiego oświadczył, że pomoc dla zaatakowanego państwa UE nie musi mieć wojskowego charakteru.

Problematyka państw neutralnych i wpływu ich członkostwa w UE na politykę bezpieczeństwa doczekała się w Polsce licznych opracowań, dlatego w tym miejscu chciałabym tylko wskazać na kilka pozycji dotyczących Austrii ${ }^{5}$.

Celem niniejszego artykułu będzie natomiast przedstawienie „Białych Ksiąg" wydawanych przez Federalne Ministerstwo Obrony Narodowej Republiki Austrii (Bundesministerium für Landesverteidigung) oraz analiza zawartych w kolejnych, ukazujących się co 2 lata (ostatnia z 2011 roku) dokumentach celów i strategii, wskazujących na zmieniające się podejście do bezpieczeństwa. Ze względu na objętość niniejszego artykułu reforma sił zbrojnych, mimo jej znaczenia dla aktywnego uczestnictwa w misjach, zostanie omówiona jedynie marginalnie, gdyż uwagę chcę skoncentrować na ewolucji polityki bezpieczeństwa i obrony.

Należy tu zaznaczyć, że Austria stosunkowo późno, bo dopiero w 2004 roku, zdecydowała o publikowaniu swych strategii w tej formie, dołączając tym samym do takich państw, jak Francja czy RFN. Księgi sta-

${ }^{3}$ Por. Heinz Fischer über Vereinbarkeit von Neutralität und EU-Mitgliedschaft bei Vortrag an der Universität Zürich w: Presseaussendungen, 26.09.2011, http://www.bundespraesident. at/newsdetail/artikel/neutralitaet-ist-ein-teil-von-oesterreichs-eu-mitgliedschaft, (dostęp 02.02.2013).

${ }^{4}$ Ibidem.

${ }^{5}$ Przede wszystkim szereg publikacji Dariusza Popławskiego - m.in. Zmierzch neutralności w Europie. Interpretacje, [w:] red. R. Kuźniar, Porządek międzynarodowy u progu XXI w. Wizje, koncepcje, paradygmaty, Wydawnictwa Uniwersytetu Warszawskiego, Warszawa 2005; Małe państwa Europy. Specyfika systemu politycznego i aktywności międzynarodowej, Wydawnictwo ASPRA, Warszawa 2009; Państwa niemieckojęzyczne w procesie integracji europejskiej. Austria, Liechtenstein, Szwajcaria, Wydawnictwo ASPRA, Warszawa 2012, Małe państwa Europy. Specyfika systemu politycznego i aktywności międzynarodowej, Wydawnictwo ASPRA, Warszawa 2009; Państwa naddunajskie w polityce zagranicznej Austrii, [w:] D. Popławski (red.), Państwa naddunajskie a Unia Europejska,Wydawnictwo ASPRA, Warszawa 2010; A. Konieczka, Polityka bezpieczeństwa Austrii, Warszawa-Toruń, Adam Marszałek, 1998; A. Szymański, Austria. Prawie petna kontynuacja [w:] J. Jasień (red.) Zmiana i kontynuacja: polityka europejska wybranych państw Unii Europejskiej, PISM, Warszawa, 2008, s. 53-54. 
nowiły rozwinięcie i konkretyzację doktryny bezpieczeństwa i obronności z 2001 r., której podstawą była zintegrowana obrony kraju przez przygotowanie się na nowe zagrożenia, dostosowanie do nich podstaw prawnych oraz rozwinięcie systemu zapobiegania zagrożeniom o charakterze militarnym i pozamilitarnym. W kolejnych edycjach Ksiąg uwzględniano nowe zagrożenia i zadania.

Powołana na podstawie powyższej doktryny w 2001 r. Narodowa Rada Bezpieczeństwa (Nationaler Sicherheitsrat) ${ }^{6}$ zadecydowała, że właśnie ta forma prezentowania zmieniającej się sytuacji bezpieczeństwa oraz związanej z tym ewolucji sił zbrojnych, najlepiej przyczyni się do ogólnospołecznej akceptacji zmian.

W 2011 roku, Urząd Kanclerski przygotował nowy dokument, noszący nazwę „Strategii bezpieczeństwa"7 zatwierdzony następnie przez rząd i skierowany do parlamentu mający zastąpić dotychczasową doktrynę. Szczególny nacisk położono $\mathrm{w}$ nim na wzmocnienie aktywność $\mathrm{w}$ ramach UE, przy zachowaniu neutralności oraz ostatecznie zrezygnowano z budzącej wiele kontrowersji i dyskutowanej w pierwszej dekadzie XXI wieku, opcji członkostwa w NATO ${ }^{8}$. Nie ma on jeszcze w 2013 roku obowiązującego charakteru.

\section{Biała Księga 2004 - Analiza, bilans, perspektywy}

Po nieudanych próbach utworzenia rządu Wielkiej Koalicji SPÖ/ ÖVP, w Austrii w dniu 4.02.2000 r., powstał rząd ÖVP koalicyjny z prawicowo-populistyczną, eurosceptyczną Wolnościową Partią Austrii (Freiheitliche Partei Osterreichs - FPÖ) J. Haidera. Kanclerzem został Wolfgang Schüssel, wicekanclerzem Susanne Riess-Passer (FPÖ). Drugi gabinet kanclerza W. Schüssela, z dwoma wicekanclerzami z FPÖ (Herbert Haupt (FPÖ), od 21.10.2003 Hubert Gorbach) rządził Austrią w okresie od 28. 02.2003 do 11.01.2007 r. ${ }^{9}$

${ }^{6}$ W 2001 r. połączono Radę ds. Polityki Zagranicznej, Radę Obrony Kraju i Radę ds. Integracji w Narodową Radę Bezpieczeństwa, które przewodniczy kanclerz i jest ona gremium doradczym rządu i ministerstw. Por. Bundeskanzleramt Österreich Nationaler Sicherheitsrat http://www.bka.gv.at/site/3504/default.aspx (dostęp 05.02.2013).

7 Österreichische Sicherheitsstrategie. Sicherheit in einer neuen Dekade - Sicherheit gestalten. w: Bundeskanzleramt Österreich, www.bka.gv.at/site/3503/default.aspx (dostęp 05.02.2013).

${ }^{8}$ Bundeskanzleramt Österreich, Österreichische Sicherheitsstrategie, http://www.bka. gv.at/site/3503/default.aspx (dostęp 05.02.2013).

9 Bundeskanzleramt Österreich, Kanzler und Regierungen seit 1945, http://www.bka. gv.at/site/3355/default.aspx (dostęp 05.02.2013). 
Istotnym jest jednak fakt, że decydującą rolę $\mathrm{w}$ kwestiach polityki, w tym polityki bezpieczeństwa, odgrywała ÖVP, której ministrowie stali na czele najważniejszych resortów, w tym obrony. Podczas drugiej kadencji W. Schüssela ukazała się pierwsza Biała Księga i została opracowana druga, opublikowana jednak już po zmianie rządu ${ }^{10}$.

Pierwsza austriacka Biała Księga 2004, z podtytułem „Analiza, bilans, perspektywy"11 została opublikowana w 50. rocznicę powstania armii austriackiej i zawierała analizę bezpieczeństwa w skali narodowej i międzynarodowej z odniesieniem do strategii europejskiej, szczegółowe przedstawienie doktryny bezpieczeństwa oraz podsumowanie debaty o stanie i przyszłości armii, a także perspektywy na kolejne lata. W przedmowie, ówczesny minister obrony, Günther Platter (ÖVP) podkreślił gotowość swego kraju do aktywnego kształtowania EPBiO, oraz wynikająca stąd niezbędną transformację sił zbrojnych ${ }^{12}$.

Dokument składał się z następujących rozdziałów: zagrożenia, ryzyka i potencjalne konflikty, rola sił zbrojnych w społeczeństwie, austriacka polityka bezpieczeństwa i obronności z odniesieniem do polityki europejskiej, narodowe i międzynarodowe podstawy prawne tej polityki, siły zbrojne (Bundesherr) w 2004 r., ekonomiczne oraz ekologiczne aspekty obronności oraz perspektywy i zalecenia Komisji ds. reformy sił zbrojnych.

Pierwsza część Księgi odnosząca się do nowych zagrożeń, szczególnie tych pozamilitarnych, nie odbiegała od katalogów zawartych w podobnych dokumentach innych państw europejskich. Wśród zagrożeń niesionych przez globalizację wymieniono tam m.in. erozję zdolności do działania i zapewniania bezpieczeństwa ze strony państw narodowych, fundamentalizm religijny i totalitarną ideologię, rozprzestrzenianie broni masowego rażenia, destabilizujące sytuację zbrojenia oraz przestępczość zorganizowaną. Ponadto nielegalne migracje, terroryzm oraz wojny cybernetyczne ${ }^{13}$.

W dokumencie wskazano na konieczność reformy sił zbrojnych adekwatnie do nowego charakteru zagrożeń i wyzwań oraz wynikających stąd nowych zdań - udziału w misjach pokojowych, interwencjach humanitarnych, prewencyjnych i stałych akcjach zapobiegających eskalacji konfliktów, czyli sil zbrojnych gotowych do działania poza granicami kraju ${ }^{14}$. $\mathrm{W}$ analizie stosunku społeczeństwa do armii, zwrócono uwagę na dwa nietypowe zjawiska - istniejącą wyraźną różnicę między deklarowanym

${ }^{10}$ Analiza polityki obu rządów w: A. Szymański, op. cit., s. 24-58.

${ }_{11}$ Bundesministerium für Landesverteidigung (hrsg.) Weißbuch 2004 Analyse Bilanz Perspektiven, Wien, März 2005, s. 314.

${ }^{12}$ Ibidem, s. 5.

${ }^{13}$ Ibidem, s. 11 i 21.

${ }^{14}$ Ibidem, s. 30. 
zaufaniem dla sił bezpieczeństwa w Austrii, oraz problemami z wstępowaniem kobiet od armii. O ile w UE badani deklarują średnio prawie ten sam poziom zaufania do policji i armii (odpowiednio 67\% i 66\%) to aż 84\% Austriaków obdarzało policję swym zaufaniem, natomiast armię jedynie $47 \%{ }^{15}$. Tę osobliwość można, moim zdaniem (w dokumencie brak jest wyjaśnienia) tłumaczyć tym, że jak wskazywały wyniki ówczesnych badan opinii publicznej dla obywateli austriackich najważniejsze było bezpieczeństwo wewnętrzne, natomiast zagrożenia zewnętrzne, nawet terroryzmem międzynarodowym, nie były tak odczuwalne i postrzegane przejściowo, uświadamiane głównie w związku w wydarzeniami w świecie, takimi jak wydarzenia z 11.09.2001 r.

W przypadku służby kobiet $\mathrm{w}$ armii austriackiej, mimo że taka możliwość istnieje już od 1998 r. (w innych państwach UE, np. RFN dopiero od 2001 r.) ich udział pozostawał w tym okresie bardzo niski (253 w $2004 \mathrm{r}$. czyli zaledwie 0,7\% wszystkich żołnierzy). Kobiety nie uczestniczyły w misjach out-of-area i mimo szeregu przywilejów gwarantowanych przez armię, zainteresowanie było niewielkie.

Wśród wymienionych w Białej Księdze celów polityki obronności (Verteidigungspolitik) znalazła się ochrona ludności, zapewnienie suwerenności oraz odpowiednio do zasobów wojskowych i pozycji Austrii, solidarne uczestniczenie w międzynarodowych misjach wojskowych, służących interesom państwa, zapobieganiu i zarządzaniu kryzysami ${ }^{16}$. Austria od początku uczestniczyła $\mathrm{w}$ strukturach i akcjach podejmowanych w ramach WPZiB, a następnie EPBiO, w Księdze znalazła się zapowiedź udziału w niemiecko-czeskiej - grupie bojowej (European Union Battlegroups - EUBG) ${ }^{17}$.

Jako zagadnienie wymagającej pogłębionej dyskusji i analizy określono kwestię charakteru przyszłej armii - czy zawodowej, czy z poboru, przytoczono jednak szereg argumentów przemawiających za utrzymaniem dotychczasowych struktur. W końcowej części Księgi przedstawiono sytuację armii oraz główne założenia jej przyszłej reformy pod nazwą "Armia 2010" (Bundesherr 2010) formułując zadania w kraju (obrona suwerenności, społeczeństwa i pomoc w przypadku klęsk żywiołowych) i oceniając wymaganą liczebność na 10000 żołnierzy ${ }^{18}$ oraz za granicą (misje

${ }^{15}$ Ibidem, s. 33.

${ }^{16}$ Ibidem, s. 35.

${ }^{17}$ Ibidem, s. 93.

18 Armia austriacka liczy w 2013 ok. 16800 żołnierzy zawodowych, ok. 12000 poborowych oraz 8600 pracowników cywilnych. W stanie gotowości wspomaganą przez 21000 milicji w rezerwie w stanie gotowości może osiągnać ok. 55 000. zob. Abfuhr für Darabos: Österreicher stimmen für Wehrpflicht w: „Die Presse” 20.01.2013http://diepresse.com/home/ politik/bundesheer/1334768/Abfuhr-fuer-Darabos_Oesterreicher-stimmen-fuer-Wehrpflicht (dostęp 10.02.2013). 
pokojowe w ramach ONZ, NATO/PdP, OBWE i EPBiO - grupy bojowe, akcje petersberskie, pomoc humanitarnych i w klęskach żywiołowych) ${ }^{19}$. Przedstawiono też proponowane zmiany struktury armii i kwestie finansowe.

Biała Księga z 2004 roku była najbardziej obszernym, prawie trzykrotnie większym niż następne, dokumentem i zawierała wiele informacji o charakterze encyklopedycznym, definicje i wyjaśnienia, szczegółowy opis kompetencji w zakresie obronności, omówiono tam także najważniejsze traktaty i ustawy oraz szczegółowo przedstawiono europejską architekturę bezpieczeństwa i obronności oraz wzajemne relacje organizacji międzynarodowych.

\section{Biała Księga 2006 - armia austriacka i polityka bezpieczeństwa i obronna}

Kolejna Biała Księga $2006^{20}$, sygnowana już przez nowego ministra obrony, Norberta Darabosa z SPÖ, została opublikowana po wygranych przez SPÖ w październiku 2006 r. wyborach i utworzeniu rządu Wielkiej Koalicji SPÖ/ÖVP, z kanclerzem Alfredem Gusenbauerem (SPÖ) i wicekanclerzem Wilhelmem Moltererem (ÖVP). Rząd ten w dużej mierze kontynuował politykę europejską i bezpieczeństwa ÖVP, popierając m.in., utworzenie sił szybkiego reagowania $\mathrm{UE}^{21}$.

W drugiej Księdze dużo miejsca poświęcono postępom w reformowaniu armii, by w ten sposób zdobyć poparcie społeczeństwa dla modernizacji Bundesheer. Jej układ przypominał poprzedni dokument i rozpoczynała się rozdziałem poświęcony zagrożeniom i aktualnej sytuacji bezpieczeństwa. Na zmiany wskazywał drugi rozdział zatytułowany „Bezpieczeństwo w europejskim środowisku"22, podkreślający priorytet unijnej EPBiO. Pozostałe części dokumentu odnosiły się do tymczasem wprowadzonych zmian prawnych, zadań armii, postępów projektu „Armia 2010”, sytuacji i działania sił zbrojnych w latach 2005 i 2006 oraz perspektyw.

W porównaniu z poprzednią Księgą, w tej wymieniono szereg nowych, wcześniej nie uwzględnionych zagrożeń - ze strony państw upadłych, szybkiego przyrostu ludności w krajach rozwijających się i po-

${ }^{19}$ Bundesministerium für Landesverteidigung (hrsg.) Weißbuch 2004..., op. cit. s. 244.

${ }^{20}$ Bundesministerium für Landesverteidigung (hrsg.) Weißbuch 2006, http://www. bmlv.gv.at/pdf_pool/publikationen/weissbuch_2006.pdf (dostęp 8.02.2013).

${ }_{21}^{2}$ A. Szymański, op. cit., s. 24.

${ }^{22}$ Sicherheitspolitik im europäischen Umfeld w: Bundesministerium für Landesverteidigung (hrsg.) Weißbuch 2006. op. cit., s. 16. 
garszającej się tam sytuacji w związku z brakiem wody i degradacją środowiska naturalnego. Wskazano też na problemy związane z ogólnymi niedoborami surowców, zarówno energetycznych (ropa naftowa, gaz) jak i innych ważnych dla gospodarek narodowych (rudy, drewno, produkty rolne), wymieniono również zagrożenia określone jako „ryzyka cywilizacyjne" (Zivilisationsrisiken) takie, jak np. klęski żywiołowe, katastrofy techniczne i ekologiczne, globalne epidemie, wywołujące zniszczenie i śmierć, destabilizujące życie polityczne i gospodarcze całych regionów oraz mogące spowodować masowe migracje ${ }^{23}$.

Wśród celów austriackiej polityki bezpieczeństwa wymieniono, oprócz wynikających z ogólnej doktryny, także takie, które wskazywały na ambicje Austrii odgrywania większej roli w Europie i na świecie - m.in. we wzmacnianiu demokracji, praw człowieka i praworządności w ramach UE, OBWE i ONZ, przejęciu większej odpowiedzialności za pokój i bezpieczeństwo w skali europejskiej i globalnej. Zaliczono tu także wyrównywanie różnic ekonomicznych w ramach dalszych rozszerzeń UE i pomocy rozwojowej, zapobieganie kryzysom gospodarczym, ochrona środowiska naturalnego i minimalizacja skutków katastrof żywiołowych ${ }^{24}$.

W części odnoszącej się do bezpieczeństwa, potwierdzono współdziałanie w Europejskiej Agencji Obrony (Austria od początku zgłosiła akces wraz z innymi państwami UE za wyjątkiem Danii) zarówno finansowe, jak i udział w projektach badawczych, m.in. współpracę w tworzeniu bazy danych biologicznych środków bojowych. Potwierdzono też wolę uczestnictwa w przyszłej grupie bojowej ${ }^{25}$.

Zawarto tam ponadto propozycje legislacyjne odnośnie do reformy sił zbrojnych, nowych struktur dowodzenia oraz przedstawiono przeprowadzone już zmiany (redukcję sił zbrojnych, zmiany w systemie powoływania na ćwiczenia rezerwistów, zmniejszenie liczby oficerów i generałów oraz obniżenie wydatków).

\section{Biała Księga 2008 i 2010}

Rząd A. Gusenbauera przetrwał jedynie półtora roku i rozpadł się po długich sporach o reformę systemu podatkowego i kwestie europejskie. W przeterminowanych wyborach we wrześniu 2008 r. obie partie rządzące poniosły duże straty, a partie prawicowe FPÖ i założony przez

\footnotetext{
${ }^{23}$ Ibidem, s. 11-14.

${ }^{24}$ Ibidem, s. 16-18.

${ }^{25}$ Ibidem, s. 26-29.
} 
J. Haidera w 2005 r. Sojusz na rzecz Przyszłości Austrii (Bündnis Zukunft Österreich-BZÖ), uzyskały wspólnie 28,2\% głosów, partia Zielonych (Grüne) 10,4\%. W tej sytuacji, gdy socjaldemokraci i centroprawica zdecydowanie odrzucili możliwość zawarcia koalicji z partiami skrajnie prawicowymi, a inne układy nie były możliwe, ponownie powstał rząd SPÖ i ÖVP, mający jednak niewielką przewagę nad opozycją 55,3\% głosów oraz dysponujący 134 mandatami ze $183^{26}$.

W gabinecie Wernera Faymanna (SPÖ) i Josefa Prölla (ÖVP) swą tekę zachował minister obrony N. Darabos. Za jego kadencji opublikowano dwa kolejne dokumenty.

Biała Księga z 2008 roku $^{27}$ stanowiła w zakresie kwestii bezpieczeństwa i zagrożeń powtórzenie treści poprzedniej księgi. Nowością było jedynie określenie zagrażających zdaniem jej autorów bezpieczeństwu Europy i Austrii regionów. Wymieniono tu nadal wolno stabilizująca się sytuację na Bałkanach i trzy potencjalne źródła zagrożenia (Kosowo, Bośnia i Hercegowina, Macedonia) oraz stałe zagrożenie na peryferiach Europy (Południowy Kaukaz, Azja Centralna, Afryka Północna, Bliski i Środkowy Wschód). Za trwałe źródła konfliktów uznano Afganistan, Irak i Liban, oraz Autonomię Palestyńską, a także regiony w Afryce ${ }^{28}$. Stwierdzono też, że wymagają one większego zaangażowania Unii Europejskiej i samej Austrii.

W Księdze zdefiniowano obszernie pojęcie zintegrowanego bezpieczeństwa (umfassende Sicherheit), czyli połączenia aspektów wewnętrznego i zewnętrznego bezpieczeństwa, w którym zarówno ważne są aspekty militarne, jak i cywilne, oraz współpraca aktorów państwowych i pozarządowych (przede wszystkich podmiotów gospodarczych, naukowców i społeczeństwa obywatelskiego) ${ }^{29}$. Politykę bezpieczeństwa winna wspierać aktywna strategia prewencji i związane $\mathrm{z}$ tym zaangażowanie $\mathrm{w}$ międzynarodowych misjach utrzymania pokoju i zapobiegania konfliktom. W tym kontekście po raz pierwszy podkreślono znaczenie współpracy z wiodącymi austriackimi instytutami naukowo-badawczymi, taki jak Österreichisches Institut für Internationale Politik, Ludwig Boltzmann-Institut, Studienzentrum für Frieden und Konfliktlösung i innymi ${ }^{30}$.

W części dotyczącej austriackiego zaangażowania w UE i innych międzynarodowych organizacjach oraz programach również powtórzono treść poprzednich dokumentów. Natomiast w rozdziałach odnoszących

${ }^{26}$ Bundesministerium für Inneres, Nationalratswahlen 2008, http://wahl08.bmi.gv.at/ (dostęp 8.02.2013).

${ }_{27}$ Bundesminister für Landesverteidigung und Sport, (hrsg.) Weissbuch 2008, Wien, 2009.

${ }^{28}$ Ibidem, s. 12.

${ }^{29}$ Ibidem, s. 16.

${ }^{30}$ Ibidem, s. 19. 
się do zadań armii można było zauważyć wyraźne przesunięcie akcentów z tradycyjnych funkcji obronny kraju na działania wewnętrznej obrony przed atakami terrorystycznymi i pomocy w klęskach żywiołowych oraz zewnętrzne - udział w misjach pokojowych i humanitarnych ${ }^{31}$.

Biała Księga z 2008 roku zawierała ponadto przypomnienie celów reformy "Armia 2010", opis tymczasem przeprowadzonych zmian oraz rozdział o etyce żołnierskiej i obowiązkach. Odbiciem toczącej się w tym czasie dyskusji o armii zawodowej, której gorącym zwolennikiem był sam minister Darabos ${ }^{32}$ był obszerny akapit, w którym przeanalizowano tę kwestię, nie zajmując jednak stanowiska. Ostatnie rozdziały odnosiły się do kwestii finansowych i wyposażenia armii, jej zadań ekologicznych, oraz zawierały opis akcji w kraju oraz zagranicznych misji w których uczestniczyła.

Ostatnią do tej pory opublikowaną Księgą była „Biała Księga 2010”33 Tym razem już we słowie wstępnym minister Darabos wyraził nadzieję na zrozumienie ze strony decydentów i opinii publicznej dla konieczności profesjonalizacji armii, po raz pierwszy artykułując w oficjalnym dokumencie swe stanowisko.

Dokument ten ukazał się już po wejściu w życie Traktatu Lizbońskiego oraz w rocznicę 50-lecia uczestnictwa Austrii w misjach pokojowych ONZ. W części odnoszącej się do zagrożeń i polityki bezpieczeństwa ponownie znalazły się zawarte $w$ poprzednich Księgach sformułowania. Novum stanowiło bezpośrednie odniesienie się do kryzysu finansowego i gospodarczego i wskazanie na jego konsekwencje - osłabienie Europy i zwiększenie wyzwań i zagrożeń dla państw europejskich ${ }^{34}$.

W Księdze przedstawiono też stanowisko Austrii wobec wprowadzonej w Traktacie Lizbońskim (art. 42 ust. 7 TUE) klauzuli wzajemnej obrony, oznaczającej że państwo członkowskie zaatakowane zbrojnie na swoim terytorium może liczyć na wsparcie pozostałych państw zobowiązanych do udzielenia pomocy ${ }^{35}$. Austria skorzystała z przewidzianej tam możliwości odstępstwa państw neutralnych („,nie ma to wpływu na szczególny charakter polityki bezpieczeństwa i obronnej niektórych Państw Członkowskich) zastrzegając, że w takim przypadku ma prawo do „,autonomicznej decyzji”36, ale deklarując równocześnie uczestnictwo we współpracy

${ }^{31}$ Ibidem, s. 37-36.

32 Abfuhr für Darabos..., op. cit.

${ }^{33}$ Bundesminister für Landesverteidigung und Sport, (hrsg.) Weissbuch 2010, Wien, 2011.

${ }^{34}$ Ibidem, s. 14.

${ }^{35}$ Wspólna polityka bezpieczeństwa i obrony, http://europa.eu/legislation_summaries/ institutional_affairs/treaties/lisbon_treaty/ai0026_pl.htm (dostęp 16.02.2013).

${ }^{36}$ Weissbuch 2010, op. cit. s. 23. 
strukturalnej. Wyeksponowano też udział Austrii w grupach bojowych, udział w misjach UE, m.in. EU FOR ALTHEA w Bośni i Hercegowinie oraz EUFOR Tchad/RCA w Republice Czadu i Republice Środkowoafrykańskiej jako godnego zaufania partnera. Podobnie jak w poprzednich latach w dokumencie wymieniono współpracę i uczestnictwo w programach innych organizacji międzynarodowych.

W części Księgi dotyczącej armii znalazł się tym razem akapit o tradycjach armii austriackiej oraz istniejących od 1969 patronatach instytucji cywilnych nad jednostkami armii, a także nowopowstałych ${ }^{37}$. Zgodnie z przyjętym układem pozostała część Księgi zawierała szczegółową analizę sytuacji w siłach zbrojnych.

Do początku 2013 roku nie ukazała się nowa Księga.

\section{Zakończenie}

Polityka bezpieczeństwa Austrii w pierwszej dekadzie XXI wieku ewoluowała, podobnie jak $\mathrm{w}$ innych państw UE, pod wpływem percepcji nowych zagrożeń i wzmacniania unijnej polityki bezpieczeństwa i obronnej. Tę ewolucję dokumentują przeanalizowane w tym artykule Białych Księgi. Zawarte w poszczególnych dokumentach idee i propozycje zaowocowały istotną zmianą jakościową w postaci, wspomnianej na wstępie, nowej strategii bezpieczeństwa narodowego z 2011 r. Stanowiła ona odpowiedź na nową koncepcję strategiczną NATO z 2010 r., wzmacniająca rolę państw uczestniczących we Partnerstwie dla Pokoju, lecz kontynuującą podstawowe zadania sojuszu obronnego. Austria jednoznacznie opowiedziała się za skoncentrowania się na większej aktywności w ramach $\mathrm{WPBiO}^{38}$. W tym projekcie polityka Austrii została określona jako „zintegrowana, aktywna i solidarna"39. Ostateczna rezygnacja z opcji członkostwa w NATO wywołała szereg komentarzy, uznano ją za zasadniczą zmianę orientacji polityki bezpieczeństwa w stosunku do zapisów dokumentu z 2001 r. $^{40}$

${ }^{37}$ Według danych $40 \%$ to przedsiębiorstwa, 18\% gminy, miasta i kraje związkowe, $12 \%$ banki i kasy oszczędnościowe, $11 \%$ związki, izby i stowarzyszenia, $10 \%$ przedsiębiorstwa energetyczne oraz 9\% instytucje ubezpieczeniowe. Ibidem, s. 44-45.

38 Por. A. Kammel, Eine Sicherheitsstrategie für Österreich: Österreichs Sicherheit (neu) gestalten? w: Austria Institut für Europa und Sicherheitspolitik (hrsg.) „Focus” 6/2011 http:// www.aies.at/publikationen/2011/fokus-11-06.php (dostęp 16.02.2013).

39 Österreichische Sicherheitsstrategie..., op. cit., s. 1.

${ }^{40}$ Por. m.in. BBN, S. Kamiński, Projekt nowej strategii bezpieczeństwa narodowego Austrii, Warszawa, maj 2011 r. www.bbn.gov.pl/.../Nowa_strat_bezp_narod_Aus. (dostęp 16.02.2013). 
W przypadku Austrii zgodę na oddelegowanie sił pokojowych w ramach organizacji międzynarodowych, jak ONZ, OBWE oraz w ramach WPBiO wyraża Komisja Główna (Hauptausschuss) Rady Narodowej (Nationalrat). W 2012 roku Austria aktywnie uczestniczyła Wzgórzach Golan, w Afganistanie, Gruzji, Bośni i Hercegowinie, w Kosowie i Kongo. Decyzje zapadały albo jednomyślnie lub większością głosów. Partie opozycyjne głosowały często przeciw - np. FPÖ przeciwko misjom w Gruzji i Kongo, na Cyprze i w Afganistanie. Także BZÖ była przeciwna dalszej obecności Austrii w Afganistanie ${ }^{41}$.

Nowa strategia bezpieczeństwa powstawała w trudnych warunkach politycznych - najpierw bojkotowanej przez UE koalicji ÖVP z FPÖ, następnie $\mathrm{w}$ trudnych układach wzajemnych dwóch głównych partii, walczących o dominację $\mathrm{w}$ koalicji, a zakończonych przedterminowymi wyborami. Reforma sił zbrojnych w dużej mierze realizowana była przez ministra Darabosa, który ze względu na swój życiorys (nie służył w armii i odbywał służbę zastępczą) nie miał oparcia w wojsku, a generałowie ostro krytykowała plan przekształcenia Bundesheer w armię zawodową, argumentując to wysokimi kosztami. Nie bez znaczenie była w tym przypadku reforma sił zbrojnych zmniejszająca liczbę wyższych oficerów i generałów. Kręgi lewicowe zarzucały natomiast próbę militaryzacji Austrii. Nie brakło też obaw, że armia zawodowa może oznaczać porzucenie neutralności i wbrew ogłoszonej w strategii 2011 deklaracji, wstąpienie do NATO. Nie pomogły argumenty o analizach podobnych procesów w innych krajach (m.in. RFN, Szwecji). W kwestii reformy armii zabrakło też zgody między koalicjantami, gdyż za zmianami była SPÖ, natomiast ÖVP optowała na rzecz dotychczasowego modelu. Ostatecznie projekt te przepadł $\mathrm{w}$ referendum, po którym minister obrony podał się do dymisji ${ }^{42}$. Pewną rolę odegrał zapewne kryzys finansowy i obawy prze nadmiernym obciążeniem budżetu, gdyż Austria mimo neutralności należy do krajów o niskich wydatkach na obronność.

Strategia bezpieczeństwa kształtowała się także w warunkach wzrastających ambicji politycznych Austrii, której jednak towarzyszyło osłabienie

${ }^{41}$ Weiter starkes Engagement Österreichs bei internationalen Missionen Hauptausschuss: Großes Lob für Leistungen österreichischer Kontingent, http://www.ots.at/presseaussendung/ OTS_20111124_OTS0330/weiter-starkes-engagement-oesterreichs-bei-internationalen-missionen-hauptausschuss-grosses-lob-fuer-leistungen-oesterreichischer-kontingent (dostęp 16.02.2013).

${ }^{42}$ Ostatecznie rząd Austrii zdecydował się na rozstrzygnięcie tej kwestii w referendum, pierwszego w historii powojennej tego państwa, które odbyło się 20.01.2013. Za utrzymaniem poboru opowiedziało się 59,7\% obywateli. Por. Wehrpflicht-Volksbefragung w: „Wien Konkret”, http://www.wien-konkret.at/politik/direkte-demokratie/volksbefragungen/wehrpflicht/ (dostęp 16.02.2013). 
armii i zmniejszanie budżetu na armię. Niepomyślny wynik referendum może negatywnie wpłynąć na przyszłą zdolność Austrii do wypełnienia zobowiązań wynikających z jej uczestnictwa w WPBiO, gdyż posiadanie armii poborowej może utrudnić Austrii uczestnictwo w niektórych formach współpracy armii państw unijnych. Tak więc stanowiące powód do dumy zaangażowanie w strukturach UE i innych międzynarodowych organizacji może z czasem okazać się utrudnione, co osłabiło by pozycję tego państwa.

We wrześniu 2013 odbędą się w Austrii wybory parlamentarne, należy zatem poczekać na ich wynik, chociaż aktualne prognozy wskazują na podobny wynik jak cztery lata temu. Czy w nowym rządzie będzie możliwe osiągnięcie większego konsensusu w kwestiach polityki bezpieczeństwa i obronnej wydaje się wątpliwe po ujawnionych w czasie referendum różnicach zdań.

\section{Zusammenfassung}

Die österreichische Sicherheits- und Verteidigungspolitik evolvierte am Anfang des 21. Jh. ähnlich wie in den anderen EU-Staaten unter dem Einfluß neuer Bedrohungen und Herasausforderungen, wie auch der Weiterentwicklung und Vertiefung Gemeinsamer Sicherheits- und Verteidigungspolitik (GSVP) der EU. Diese Entwicklung bezeugen die sog. „Weißbücher", aus den Jahren 2004, 2006, 2006 und 2010, die im Beitrag analysiert wurden. In den einzelnen Weißbücher wurden die diversen Aspekte der Sicherheit mit Bezug auf österreichische Neutralität besprochen, wie auch die in dieser Zeitspanne vorgenommenen Reformen des Bundesheeres detailliert dargestellt. Die Verfasserin berücksichtigt das sich verändernde politische Umfeld dieser Entwicklung (Koalition SPÖ/FPÖ in den Jahren 2000 -2007 und spätere Meinungsverschiedenheiten der SPÖ/ ÖVP-Regierungen 2008-2013 bis zur ersten in der Geschichte Österreichs Volksbefragung über die Wehrpflicht im Januar 2013). Es wurde auch die noch nicht geltende neue Sicherheitsstrategie aus dem Jahre 2011 erwähnt, welche eine entscheidenden Absage der lange diskutierten NATO-Annährung, bzw. Beitritt bedeutete. Ferner wurde auch die Stellung Österreichs zur Beistandshilfeklausel im Lissabon Vertrag thematisiert. In den Schlußfolgerungen wird betont, daß inzwischen eine Kluft zwischen den Engagement und Aspiration Österreichs als einen europäischen und globalen Akteur im Bereich der Konfliktverhütung und Friedensmissionen, und den Probleme mit der Bundesheerreform zu entstehen scheint. 